\title{
Factors Affecting Optimal Continuous Positive Airway Pressure Level in Patients with Obstructive Sleep Apnea Syndrome
}

\author{
Obstrüktif Uyku Apne Sendromlu Hastalarda Optimal Sürekli Pozitif Havayolu \\ Basınç Düzeyini Etkileyen Faktörler \\ Hulya Gunbatar ${ }^{1}$, Havva Sayhan Kaplan ${ }^{2}$ \\ ${ }^{1}$ Yuzuncu Yil University Medical Faculty, Department of Pulmonary and Critical Care, Van, Turkey \\ ${ }^{2}$ Yuzuncu Yil University, Department of Anesthesiology and Reanimation, Van, Turkey \\ Yazıșma Adresi / Correspondence: \\ Havva Sayhan Kaplan \\ Yuzuncu Yil University, Department of Anesthesiology and Reanimation Y.Y.U. D. Odabas Tip Merkezi Kampüs/ Van /Turkey \\ T: +90432 2150470 - $6135 \quad$ E-mail: hsayhan@gmail \\ Geliş Tarihi / Received : 21.01.2020 Kabul Tarihi / Accepted : 06.03.2020 \\ Orcid : \\ Hulya Gunbatar https://orcid.org/0000-0002-3504-8915 \\ Havva Sayhan Kaplan https://orcid.org/0000-0001-7682-2666 \\ ( Sakarya Med J / Sakarya Tip Dergisi 2020, 10(1):99-106 ) Doi: 1031832678074
}

\begin{abstract}
Objective This study aimed to examine factors (BMI, neck circumference, AHI etc.) affecting optimal CPAP levels in patients with obstructive sleep apnea syndrome (OSAS),

Materials A total of 120 patients with OSAS who underwent successful auto-titration for CPAP treatment were included in this study. Correlations between the optimal CPAP level and Methods and baseline data were analyzed.

Results The mean optimal pressure level in the 120 OSAS patients was $9.11 \pm 2.81 \mathrm{~cm} \mathrm{H} 2 \mathrm{O}$. The mean optimal pressure levels in the mild, moderate, and severe OSAS groups were $8.01 \pm 2.60,8.32 \pm 2.22$, and $9.71 \pm 3.01 \mathrm{~cm} \mathrm{H} 2 \mathrm{O}$, respectively. Apnea/hypopnea index (AHI) $(\mathrm{r}=0.297, \mathrm{p}<0.001)$ and minimal SaO2 $(\mathrm{r}=-0.264, \mathrm{p}<0.004)$ were significantly correlated with optimal pressure level. 22 patients in the titration failure group had severe AHI overall; 6 patients had REM-related and 2 had position-related OSAS. Patients in the titration failure group who did not have a specific diagnosis (rapid eye movement (REM) or positional OSAS) had very severe AHI levels (mean AHI of $67.90)$

Conclusions According to the correlation tests, AHI and the lowest saturation were the two most important predictors of optimal CPAP level.

Keywords Obstructive sleep apnea syndrome; Continuous positive airway pressure; Polysomnography; Apnea
\end{abstract}

$\ddot{\mathrm{O} z}$

Amaç Bu çalssmada obstrüktif uyku apne sendromu (OUAS) olan hastalarda optimal CPAP düzeylerini etkileyen faktörlerin (VKİ, boyun cevresi, AHİ vb.) araștırlllması amaçlandı.

Gerec ve

Yöntemler Bu çalıșmaya CPAP tedavisi için bașarılı oto titrasyon uygulanan 120 OUAS hastası dahil edildi. Optimal CPAP seviyesi ile bașlangı̨̧ verileri arasındaki korelasyonlar analiz edildi.

Bulgular

120 OUAS hastasında ortalama optimal basınç seviyesi $9.11 \pm 2.81 \mathrm{~cm} \mathrm{H2O} \mathrm{idi.} \mathrm{Hafif,} \mathrm{orta} \mathrm{ve} \mathrm{şiddetli} \mathrm{OUAS} \mathrm{gruplarinda} \mathrm{ortalama} \mathrm{optimal} \mathrm{basınç} \mathrm{seviyeleri} \mathrm{sirastyla} 8.01 \pm 2.60,8.32 \pm 2.22$ ve $9.71 \pm 3.01 \mathrm{~cm}$ H2O idi. Apne / hipopne indeksi (AHI) $(r=0.297, p<0.001)$ ve minimal SaO2 $(r=-0.264, p<0.004)$ optimal bastnç seviyesi ile anlaml korelasyon gösterdi. Titrasyon yetmezliği grubundaki 22 hastada genel olarak ağır AHI vardl; 6 hastada REM ilișkili, 2 hastada pozisyona bağlı OUAS mevcuttu. Titrasyon yetmezliği grubunda, belirli bir tanısı (hızlı göz hareketi (REM) veya pozisyon OUAS) bulunmayan hastalarda çok ciddi AHI düzeyleri vardı (ortalama AHI 67.90 idi).

Sonuc Korelasyon testlerine göre optimal CPAP seviyesinin en önemli iki belirleyicisi AHI ve en düsük saturasyon olarak bulundu.

Anahtar Kelimeler Obstrüktif uyku apne sendromu; Sürekli pozitif havayolu bastncl; Apne; Polisomnografi 


\section{Introduction}

Obstructive sleep apnea syndrome (OSAS) is characterized by collapse of the upper airway during sleep, recurring apnea, intermittent hypoxemia, and daytime sleepiness, and associated with decreased daytime performance and impaired quality of life. ${ }^{1}$

OSAS is a common sleep-breathing disorder that is estimated at least between $9 \%$ and $25 \%$ in the general population, and most patients are not aware of their illness. ${ }^{2}$ Even asymptomatic OSAS is known to be associated with increased morbidity and mortality. ${ }^{3}$ Patients undergoing surgery also have a high prevalence in OSAS and it is known that there is an increase in postoperative complications compared to general population. ${ }^{4,5}$ It is possible to suspect from OSAS with preoperative osas screening surveys conducted in the anesthesia outpatient clinic. These patients would benefit from sleep medicine referral, expedited polysomnography (PSG), and continuous positive airway pressure (CPAP) treatment. ${ }^{6}$

Positive airway pressure (PAP) is a standard treatment for patients with OSAS. Three titration methods are used to determine the mean optimal pressure level: full-night, split-night, and auto-titrating positive airway pressure (APAP). Of these, full-night, attended titration with PSG is the gold standard for the determination of an optimal CPAP level. ${ }^{7}$ Although the preferred method in a sleep laboratory is full-night manual titration, APAP titration may be performed to identify optimal CPAP levels for patients with moderate to severe OSAS who do not have additional diseases (e.g., chronic obstructive pulmonary disease, or hypoventilation syndrome) ${ }^{8}$

Accredited centers' protocols and procedures described for PAP titration vary widely among accredited centers' protocols. ${ }^{9,10}$ Several factors have been identified as potentially affecting optimal pressure, such as amount of rapid eye movement (REM) sleep, length of the soft palate, and degree of respiratory effort. ${ }^{11,12}$ Additionally, one might re- ason that the level of optimal PAP is correlated with OSAS severity and/or obesity; i.e. higher levels of PAP would be needed to control respiratory events in patients with severe OSA and/or those who are morbidly obese.

Although some studies have shown a good correlation between optimal CPAP levels and the apnea/hypopnea index (AHI) or obesity, this opinion has not been consistently supported in the literature. ${ }^{13,14}$ A significant correlation for optimal CPAP and AHI has been observed only in patients whose sleep apnea is dependent on body position. ${ }^{15}$ If the patient is uncomfortable or intolerant of high pressures on CPAP, or if there are continued obstructive respiratory events at $15 \mathrm{~cm} \mathrm{H} 2 \mathrm{O}$ of CPAP during the titration study, CPAP may be switched to Bilevel Positive Airway Pressure (BPAP). ${ }^{16}$

Various predictive formulas for optimal CPAP levels have been developed in several countries and for populations of different geographical origin. ${ }^{17,18,19}$ The optimal CPAP level as determined using a predictive equation may improve the success rate of manual titration and increase the simplicity of treatments such as self-titration of CPAP or APAP. ${ }^{20,21}$. With this in mind, the objectives of the present study were: 1) to determine the mean optimal CPAP level according to the severity of OSAS; and 2) to examine the factors that influence the optimal CPAP level in patients with OSAS.

\section{Materials and Methods Subjects}

All patients who were referred to the chest service and anesthesia outpatient clinic for preoperative preparation diagnosed with OSAS using the AHI with a standard polysomnographic test ( $\geq 15$ on the Epworth Sleepiness Scale) who reported snoring, apnea, or daytime sleepiness, and who underwent successful manual titration for CPAP treatment between June 2017 and June 2018, were included in the cross-sectional descriptive study after Yuzuncu Yil University's Faculty of Medicine Review Board 
(17.01.2020 - 2020 / 01-03) approved the study. Records of consecutive 120 patients were extracted from hospital registry.

Patients were selected consecutively. Demographic and health behavior-related data, including age, sex, body mass index (BMI), Epworth Sleepiness Scale scores, and medical histories regarding sleep habits and cardiovascular disease were collected from patient records. Mild, moderate, and severe OSAS for adults was defined as $5 \leq \mathrm{AHI}<15$, $15 \leq \mathrm{AHI}<30$, and $\mathrm{AHI} \geq 30$, respectively. ${ }^{22}$ Neck circumference $(\mathrm{cm})$ was measured at the level just below the most prominent portion of the thyroid cartilage (Adam's apple).

\section{Polysomnography and CPAP titration}

Overnight polysomnography was performed with 16-channel Embla (Medcare Inc, Reykjavik, Iceland) continuous sleep technician monitoring. The system consists of 4 channels of EEG (with electrode placements at C4-A1, C3-A2, O2-A1, and O1-A2), 2 channels of EOG, submental EMG, oronasal air flow, thoracic and abdominal movements, pulse-oximetry oxygen saturation, tibial EMG, body position detector, an electrocardiogram, and tracheal sound. Apnea was defined as the complete cessation of airflow lasting more than 10 seconds. Hypopnea was defined as a $>30 \%$ reduction in airflow lasting more than 10 seconds accompanied by $>4 \%$ desaturation and/or arousal. The average number of episodes of apnea and hypopnea per hour of sleep were measured as AHI. The diagnosis of OSAS was made on the basis of AHI $>5$.

Sleep stages were scored following standard criteria with 30 -second epochs and reviewed and verified by a certified sleep physician. The optimal pressure level was defined as the lowest effective pressure that brought most respiratory disturbances under control (including apnea, hypopnea, and snoring) for all body positions (especially in the supine position during REM sleep) and in all stages. Auto-titration was performed with the same PSG recording montage to determine the optimal pressure level for CPAP treatment.

\section{Statistical analysis}

Statistical analyses were performed using SPSS software version 20 (IBM; Armonk, New York, USA). Continuous data are expressed as means \pm standard deviation (SD). Statistical comparisons were performed using a one-way analysis of variance (ANOVA) and chi-square test. Pearson's correlation coefficients were calculated to separately determine the relationships between these variables in each group, Overall AHI in patient whose symptoms were controlled or not controlled by their titration regimens (referred to as the failure and success groups, respectively) was assessed and used in the separating cut-off value for receiver operating characteristic (ROC) analysis. A p value $<0.050$ was considered statistically significant.

\section{Results}

The anthropometric and polysomnographic variables according to the severity of OSAS are shown in Table 1 . The mean optimal pressure level in the 120 OSAS patients was $9.11 \pm 2.81 \mathrm{~cm} \mathrm{H} 2 \mathrm{O}$. The mean optimal pressure levels in the mild, moderate, and severe OSAS groups were $8.01 \pm$ $2.60,8.32 \pm 2.22$, and $9.71 \pm 3.01 \mathrm{~cm} \mathrm{H} 2 \mathrm{O}$, respectively. The titration failure group consisted of patients who were uncomfortable because of the high pressure and in whom respiratory obstruction continued to cause events at $15 \mathrm{~cm}$ $\mathrm{H} 2 \mathrm{O}$ of CPAP; this group was switched to BPAP. Anthropometric and polysomnographic variables in the failure and success groups are shown in Table 2. Anthropometric and polysomnographic variables in the failure group are shown in detail in Table 3 . The roc curve for AHI in the failure group is shown in Figure 1.

Table 4 presents the correlations among the 120 patients between the baseline variables (including demographic and polysomnographic data) and the optimal pressure level for CPAP treatment. AHI $(r=0.297, \mathrm{p}<0.001)$ and minimal SaO2 $(r=-0.264, \mathrm{p}<0.004)$ were significantly correlated with optimal pressure level. 
Sakarya Med J. 2020;10(1):99-106

GÜNBATAR et al., Factors Affecting Optimal Continuous Positive Airway Pressure Level in Obstructive Sleep Apnea Syndrome

\begin{tabular}{|c|c|c|c|c|c|}
\hline & & Mild $(\mathrm{n}=18)$ & Moderate $(\mathrm{n}=31)$ & Severe $(n=71)$ & Total $(n=120)$ \\
\hline \multirow{4}{*}{ 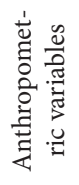 } & Age: years $\pm \mathrm{SD}$ & $49.30 \pm 9.10$ & $50.31 \pm 11.61$ & $49.11 \pm 11.61$ & $49.50 \pm 11.20$ \\
\hline & Sex (n) (male:female) & $12: 6$ & 22:9 & $58: 13$ & 92:28 \\
\hline & Neck circumference $(\mathrm{cm} \pm \mathrm{SD})$ & $37.92 \pm 3.41$ & $37.51 \pm 2.81$ & $39.60 \pm 3.32$ & $38.80 \pm 3.31$ \\
\hline & Body mass index (kg/m2 $\pm \mathrm{SD})$ & $33.11 \pm 6.72$ & $32.00 \pm 5.32$ & $33.11 \pm 5.51$ & $32.80 \pm 5.61$ \\
\hline \multirow{6}{*}{ 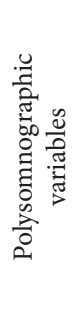 } & Mean optimal CPAP (range \pm SD) & $8.01 \pm 2.61$ & $8.31 \pm 2.21$ & $9.70 \pm 3.01$ & $9.10 \pm 2.80$ \\
\hline & AHI overall (events/hour of TST \pm SD)) & $10.51 \pm 3.01$ & $21.76 \pm 4.55$ & $60.80 \pm 26.37$ & $43.11 \pm 29.71$ \\
\hline & Minimal SaO2 $(\% \pm S D)($ at first PSG $)$ & $77.53 \pm 12.47$ & $74.18 \pm 11.41$ & $69.30 \pm 10.91$ & $71.80 \pm 11.61$ \\
\hline & Desaturation time $(\mathrm{sec} \pm \mathrm{SD})$ under $\% 90 \mathrm{SaO} 2$ & $50.36 \pm 74.93$ & $86.29 \pm 92.94$ & $110.01 \pm 121.32$ & $95.01 \pm 110.11$ \\
\hline & Minimal SaO2 $(\% \pm \mathrm{SD}))($ at titration $)$ & $82.06 \pm 10.51$ & $82.1 \pm 10.11$ & $83.04 \pm 7.82$ & $82.67 \pm 8.82$ \\
\hline & $\begin{array}{l}\text { Desaturation time }(\sec \pm \mathrm{SD})(\text { at titration }) \text { under } \\
\% 90 \mathrm{SaO} 2\end{array}$ & $30.84 \pm 49.22$ & $43.06 \pm 65.09$ & $39.02 \pm 61.35$ & $38.80 \pm 60.31$ \\
\hline $\begin{array}{l}\text { Values } \\
\text { Abbre } \\
\text { apnea }\end{array}$ & $\begin{array}{l}\text { given as the mean } \pm \mathrm{SD} \\
\text { ions: CPAP, continuous positive airway pressur } \\
\text { drome; TST: total sleep time; AHI: apnea-hypo }\end{array}$ & $\begin{array}{l}\text { S, obstructi } \\
\text { dex. }\end{array}$ & & & \\
\hline
\end{tabular}

\begin{tabular}{|l|c|c|c|}
\hline Table 2- Antropometric and polysomnographic variables in successful and failure titration group \\
\hline & Successful $(\mathrm{n}=98)$ & Failure $(\mathrm{n}=22)$ & P value \\
\hline Age: years \pm SD & $49.90 \pm 10.80$ & $47.33 \pm 12.54$ & 0.320 \\
\hline Body mass index $\left(\mathrm{kg} / \mathrm{m}^{2} \pm \mathrm{SD}\right)$ & $32.56 \pm 5.90$ & $34.21 \pm 4.25$ & 0.220 \\
\hline Neck circumference $(\mathrm{cm} \pm \mathrm{SD})$ & $38.83 \pm 3.34$ & $38.90 \pm 3.61$ & 0.880 \\
\hline AHI overall (events/hour of TST \pm SD)) & $39.76 \pm 28.01$ & $58.43 \pm 32.82$ & 0.007 \\
\hline Mean pressure & $8.09 \pm 1.86$ & $13.81 \pm 1.41$ & 0.001 \\
\hline Minimal SaO2 $(\% \pm S D)($ at first PSG) & $73.30 \pm 11,00$ & $65.10 \pm 12.32$ & 0.003 \\
\hline AHI(events/hour of TST \pm SD) attitration & $5.43 \pm 9.76$ & $8.84 \pm 12.22$ & 0.160 \\
\hline Minimal SaO $(\% \pm S D)$ (at titration ) & $83.03 \pm 8.62$ & $81.05 \pm 9.71$ & 0.344 \\
\hline $\begin{array}{l}\text { Values are given as the mean } \pm \text { SD } \\
\text { Abbreviations: TST, total sleep time; AHI, apnea-hypopnea index; PSG, Polysomnography }\end{array}$ & & \\
\hline
\end{tabular}

22 patients in the titration failure group had severe AHI overall; 6 patients had REM-related and 2 had position-related OSAS. Patients in the failure group who did not have a specific diagnosis (rapid eye movement (REM) or positional OSAS) had very severe AHI levels (mean AHI of 67.90).

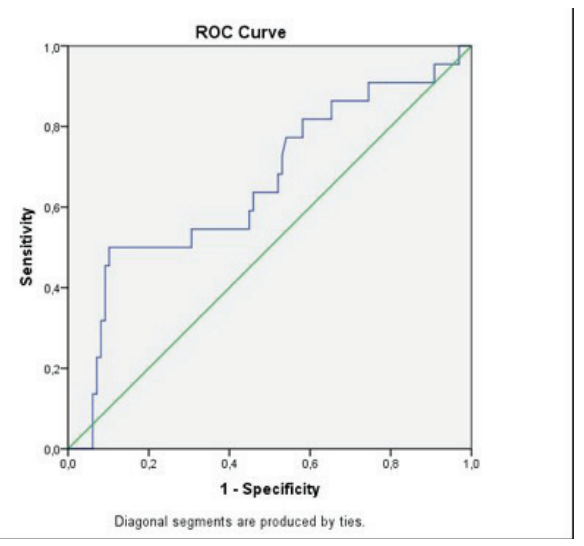

Figure 1: The roc curve for AHI in the failure group 
Sakarya Med J. 2020;10(1):99-106

GÜNBATAR et al., Factors Affecting Optimal Continuous Positive Airway Pressure Level in Obstructive Sleep Apnea Syndrome

\begin{tabular}{|c|c|c|c|c|c|c|c|c|c|c|c|c|}
\hline & 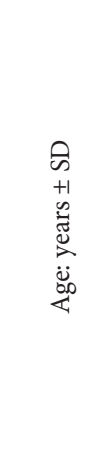 & 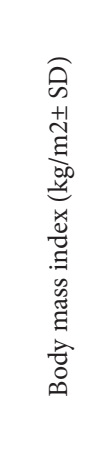 & 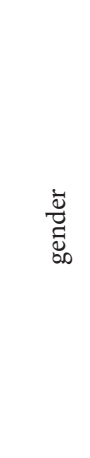 & 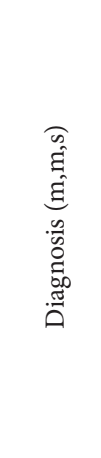 & 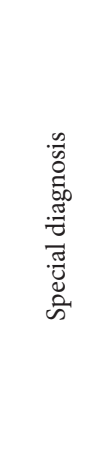 & 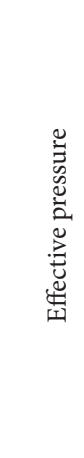 & 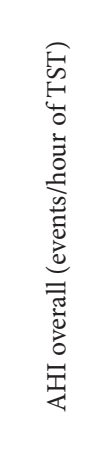 & 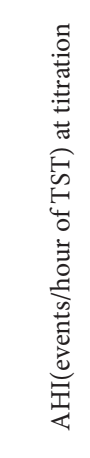 & 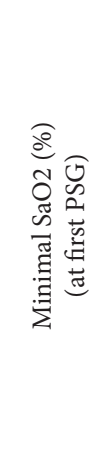 & 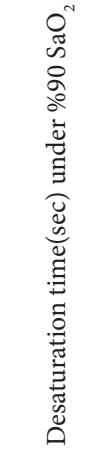 & 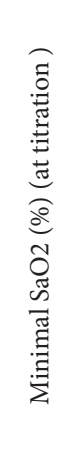 & 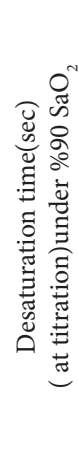 \\
\hline 1 & 36 & 37,10 & $\mathrm{~F}$ & Sev re & $\begin{array}{l}\text { rem } \\
\text { related }\end{array}$ & 12,61 & 99.00 & 15,62 & 50 & 44,40 & 65 & 74 \\
\hline 2 & 52 & 35,20 & M & Severe & $\begin{array}{l}\text { rem } \\
\text { related }\end{array}$ & 14,61 & 37,63 & 5,62 & 61 & 107 & 79 & 75 \\
\hline 3 & 68 & 42,21 & $\mathrm{~F}$ & Severe & $\begin{array}{l}\text { rem } \\
\text { related }\end{array}$ & 13,72 & 36,55 & 8.00 & 65 & 51 & 81 & 179 \\
\hline 4 & 59 & 41.00 & $\mathrm{~F}$ & Severe & $\begin{array}{l}\text { rem } \\
\text { related }\end{array}$ & 12.00 & 71,31 & 17.00 & 71 & 129 & 85 & 7 \\
\hline 5 & 40 & 32,32 & $\mathrm{M}$ & Severe & & 12,74 & 80,20 & 8.00 & 61 & 44 & 80 & 1 \\
\hline 6 & 42 & 30,71 & $\mathrm{M}$ & Mild & $\begin{array}{l}\text { Position } \\
\text { related }\end{array}$ & 12,36 & 33,45 & 0,55 & 84 & 20 & 90 & 0 \\
\hline 7 & 45 & 33,11 & M & Severe & & 15,28 & 81.09 & 5,67 & 66 & 16 & 84 & 2,55 \\
\hline 8 & 32 & 31,26 & $\mathrm{M}$ & Severe & & 15.00 & 98.04 & 6,23 & 61 & 32,33 & 84 & 1 \\
\hline 9 & 32 & 28,45 & $\mathrm{M}$ & Severe & $\begin{array}{l}\text { Position } \\
\text { related }\end{array}$ & 14,73 & 46.00 & 0,67 & 82 & 6,73 & 90 & 0 \\
\hline 10 & 63 & 43.00 & F & Severe & & 17,57 & 95.00 & 0,74 & 55 & 341 & 80 & 21 \\
\hline 11 & 62 & 31,31 & F & $\begin{array}{l}\text { Moder- } \\
\text { ate }\end{array}$ & $\begin{array}{l}\text { rem } \\
\text { related }\end{array}$ & 12,20 & 50,53 & 0,74 & 53 & 231 & 74 & 199 \\
\hline 12 & 53 & 32,70 & M & Severe & & 14.00 & 70,53 & 0.00 & 69 & 55 & 90 & 0 \\
\hline 13 & 41 & 37,24 & $\mathrm{M}$ & Severe & & 14.00 & 88,93 & 43,77 & 68 & 365 & 83 & 0 \\
\hline 14 & 49 & 36,28 & F & $\begin{array}{l}\text { Moder- } \\
\text { ate }\end{array}$ & $\begin{array}{l}\text { rem } \\
\text { related }\end{array}$ & 15,35 & 32,89 & 0.00 & 78 & 23 & 89 & 0 \\
\hline 15 & 53 & 30,15 & M & Severe & & 13,12 & 78,74 & 0.00 & 75 & 33 & 90 & 0 \\
\hline 16 & 72 & 34,43 & F & $\begin{array}{l}\text { Moder- } \\
\text { ate }\end{array}$ & & 12,92 & 47.98 & 6,67 & 50 & 278 & 63 & 156 \\
\hline 17 & 28 & 36,39 & $\mathrm{M}$ & Severe & & 13,73 & 99,25 & 23,37 & 51 & 246 & 52 & 59 \\
\hline 18 & 33 & 26,31 & M & Mild & $\begin{array}{l}\text { Position } \\
\text { related }\end{array}$ & 15.00 & 53,51 & 37,62 & 90 & 0 & 87 & 0 \\
\hline 19 & 32 & 32,76 & $\mathrm{M}$ & Severe & & 12,91 & 80,51 & 0,95 & 50 & 243 & 83 & 12,52 \\
\hline 20 & 45 & 35,78 & M & Severe & & 16.00 & 88,66 & 13,71 & 80 & 16,93 & 86 & 0 \\
\hline 21 & 53 & 31,12 & M & Severe & & 13,32 & 91,87 & 0,63 & 62 & 144 & 83 & 13 \\
\hline 22 & 52 & 34,42 & M & Severe & & 11,85 & 30,79 & 0.00 & 51 & 4 & 85 & 0 \\
\hline \multicolumn{13}{|c|}{$\begin{array}{l}\text { Values are given as the mean } \pm \mathrm{SD} \\
\text { Abbreviations: TST, total sleep time; AHI, apnea-hypopnea index; PSG, Polysomnography; F, female; } \\
\mathrm{M} \text {, male }\end{array}$} \\
\hline
\end{tabular}


Sakarya Med J. 2020;10(1):99-106

GÜNBATAR et al., Factors Affecting Optimal Continuous Positive Airway Pressure Level in Obstructive Sleep Apnea Syndrome

\begin{tabular}{|c|c|c|c|c|}
\hline & & OSAS $(n=120)$ & $\begin{array}{l}\text { Correlation } \\
\text { coefficient }(\mathrm{r})\end{array}$ & $P$ value \\
\hline \multirow{3}{*}{$\begin{array}{l}\text { Anthropometric } \\
\text { variables }\end{array}$} & Age: years \pm SD & $49.52 \pm 11.26$ & -0.022 & 0.811 \\
\hline & Body mass index $\left(\mathrm{kg} / \mathrm{m}^{2} \pm \mathrm{SD}\right)$ & $32.84 \pm 5.12$ & 0.037 & 0.689 \\
\hline & Neck circumference $(\mathrm{cm} \pm \mathrm{SD})$ & $38.87 \pm 3.31$ & 0.130 & 0.159 \\
\hline \multirow{3}{*}{$\begin{array}{c}\text { Polysomnographic } \\
\text { variables }\end{array}$} & AHI overall (events/hour of TST \pm SD & $43.11 \pm 29.71$ & 0.297 & 0.001 \\
\hline & $\begin{array}{c}\text { Minimal } \mathrm{SaO}_{2}(\% \pm \mathrm{SD}) \\
\text { (at first PSG) }\end{array}$ & $71.80 \pm 11.61$ & -0.264 & 0.004 \\
\hline & $\begin{array}{c}\text { Minimal } \mathrm{SaO}_{2}(\% \pm \mathrm{SD}) \\
\text { (at titration) }\end{array}$ & $82.62 \pm 8.81$ & 0.156 & 0.920 \\
\hline \multicolumn{5}{|c|}{$\begin{array}{l}\text { Relationship between optimal CPAP level and baseline variables in } 120 \text { patients with OSAS } \\
\text { Values are given as the mean } \pm \text { SD } \\
\text { Abbreviations: CPAP, continuous positive airway pressure; OSAS, obstructive sleep } \\
\text { apnea syndrome; TST, total sleep time; AHI, apnea-hypopnea index; PSG, Polysomnography }\end{array}$} \\
\hline
\end{tabular}

The relationships between optimal CPAP level and baseline variables were as follows. Minimal SaO2 (\%) was negatively correlated and desaturation time under $90 \%$ was positively correlated with AHI for all 3 levels of OSAS severity. In the REM-related OSA group, optimal CPAP level was positively correlated with AHI overall and negatively correlated with minimal $\mathrm{SaO} 2$.

The effective pressures for our patients were compared with those yielded by the prediction formulas developed by Hoffstein for Caucasian populations and by Lin for Asian populations. ${ }^{17,23}$ The mean predicted pressure (Ppred) calculated from the group in whom the Hoffstein formula was used was $7.21 \pm 1.75 \mathrm{~cm} \mathrm{H} 2 \mathrm{O}$, and with use of the Lin formula was $8.24 \pm 1.63 \mathrm{~cm} \mathrm{H} 2 \mathrm{O}$. These formulas were also positively correlated with the effective pressure level. $28 \%$ of 120 patients were patients referred from the Anesthesia outpatient clinic, and CPAP was performed for 2 weeks and their operations were delayed.

\section{Discussion}

The objective of this study was to observe the causes of titration failure for optimal CPAP level during diagnostic evaluation in OSAS patients.

Nasal CPAP has been the gold standard of treatment for OSAS. Traditionally, the implementation of CPAP has required an in-laboratory CPAP titration procedure that can be costly and time-consuming while limiting access to therapy.

Several previously mentioned factors have been identified as potentially affecting optimal pressure, including amount of REM sleep, length of the soft palate and the degree of respiratory effort, OSA severity, and/or obesity and body position. In the present study, 8 prediction variables (age, gender, NC, BMI, AHI, lowest SpO2, desaturation time under $90 \% \mathrm{SaO} 2$, and REM-related or position-related sleep apnea) were used in the Pearson's correlation analysis. AHI $(r=0.297, \mathrm{p}<0.010)$ and minimal SaO2 $(r=-0.264$, $\mathrm{p}<0.010)$ were significantly correlated with optimal pressure level.

Various solutions have been posed as alternatives to conventional titration in individuals with OSA, including pressure prediction using mathematical formulas. ${ }^{24,25,26}$ These prediction formulas cannot replace CPAP titration, but rather predict optimal titration levels. Several formulas exist in which an equation to predict the optimal pressure is different depending on ethnic group. ${ }^{14,17,23}$ Akahoshi et al. produced a predictive equation derived from anthropometric, polysomnographic, and cephalometric data in 170 Japanese patients with OSAS.19 The inclusion of mean saturation differentiated this formula from others. Basoglu 
and Tasbakan produced a predictive equation derived only from the circumference of the neck and the oxygen desaturation index..$^{27}$ According to their new formula, no significant difference existed between Ppred and Hoffstein's or Lin's formulas. These researchers comment in particular that race/ethnicity may not be an important factor in predicting CPAP levels. Habesoglu and Kokturk concluded that Ppred calculated by patients based on anthropometric properties and formula based on apnea hypopnea index and automated titration pressures were correlated with each other. ${ }^{28}$

We also compared the effective pressures with the prediction formulas developed by Hoffstein[18] for Caucasian populations and by Lin for Asian populations. ${ }^{17,23}$ Our effective pressure levels closely agreed with these equations; a positive correlation existed between mean effective pressure and results from Hoffstein's and Lin's equations. However, this correlation did not exist in the failure group. The $18 \%$ failure detected is considerable when we compare automatic titration pressure (Paut) and estimated (calculated) titration pressure (Ppred) to evaluate the benefits of predicting CPAP pressure in CPAP treatment. Our clinical experience is that titration should be performed with different devices for the second and even third time in these cases. Patients with morbid obesity, deep desaturation on deep REM period during all night sleep and very high AHI values, , the AHI was 67.9 in our failed group, should be monitored more closely. We believe that the titration priority should be BPAP.

According to the correlation tests, AHI and the lowest saturation were the two most important predictors of optimal CPAP level; neither Lin's nor Hoffstein's equations included lowest saturation level. In the evaluation of OSA related to REM and position, the failure percentages were $26.90 \%$ for REM-related OSA and $13.70 \%$ for position-related OSA; in the failure group, both of these OSA groupings had severe overall AHI levels. The mean AHI was 67.90 in the failure group that did not have REM-related or position-related OSA. This number is very high in OSA patients in general, and also brings about the lowest saturation levels. The possibility exists that the terminology related to mild, moderate, severe, and very severe OSAS will change over time. BPAP auto titration could be performed in patients with additional diseases such as congestive heart failure, chronic obstructive pulmonary disease, or hypoventilation syndrome as well as in those with very severe OSA.

In conclusion, a predictive equation for optimal CPAP level could be developed using $\mathrm{AHI}$ and minimal $\mathrm{SaO} 2$ (\%) in a larger patient series, which can be easily measured during diagnostic polysomnography. Predictive equations for optimal CPAP level should be helpful for designing optimal titration protocols in patients who have simple OSAS without additional diseases, severe REM-related or position-related OSAS, or very severe OSA. Predictive equations for simple OSA would be preferable to manual titration, which is costly and time-consuming and would require waiting for treatment, limiting access.

\section{Acknowledgments}

Funding-No funding was received for this research.

\section{All authours have no conflict of interest to disclouse}

All procedures performed in studies involving human participants were in accordance with the ethical standards of the institutional and/or national research committee and with the 1964 Helsinki declaration and its later amendments or comparable ethical standards.

\section{Informed consent}

Informed consent was obtained from all individual participants included in the study. This research did not receive any specific grant from funding agencies in the public, commercial, or not-for-profit sectors.

The study was approved by the Yuzuncu Yil University's Faculty of Medicine Review Board (17.01.20202020/01-03) 
Sakarya Med J. 2020;10(1):99-106

GÜNBATAR et al., Factors Affecting Optimal Continuous Positive Airway Pressure Level in Obstructive Sleep Apnea Syndrome

\section{References}

1. Young T, Palta M, Dempsey J, Skatrud J, Weber S, Badr S. The occurrence of sleep-disordered breathing among middle-aged adults. N Engl J Med. 1993 Apr 29;328(17):1230-5.

2. Peppard PE, Young T, Barnet JH, Palta M, Hagen EW, Hla KM. Increased prevalence of sleep-disordered breathing in adults. Am J Epidemiol. 2013;177(9):1006-1014

3. Young T, Finn L, Peppard PE, et al. Sleep disordered breathing and mortality: eighteen year follow up of the Wisconsin Sleep Cohort. Sleep 2008; 31: 1071-8P

4. Kaw R, Michota F, Jaffer A, Ghamande S, Auckley D, Golish J. Unrecognized sleep apnea in the surgical patient: implications for the perioperative setting. Chest 2006; 129: 198-205

5. Liao P, Yegneswaran B, Vairavanathan S, Zilberman P, Chung F. Postoperative complications in patients with obstructive sleep apnea: a retrospective matched cohort study. Can J Anaesth 2009; 56: 819-28

6. Society of Anesthesia and Sleep Medicine Guidelines on Preoperative Screening and Assessment of Adult Patients With Obstructive Sleep Apnea.Chung F, Memtsoudis SG, Ramachandran SK, Nagappa M, Opperer M, Cozowicz C, Patrawala S, Lam D, Kumar A, Joshi GP, Fleetham J, Ayas N, Collop N, Doufas AG, Eikermann M, Englesakis M, Gali B, Gay P, Hernandez AV, Kaw R, Kezirian EJ, Malhotra A, Mokhlesi B, Parthasarathy S, Stierer T, Wappler F, Hillman DR, Auckley D .Anesth Analg. 2016;123(2):452.

7. Epstein LJ, Kristo D, Strollo PJ Jr, Friedman N, Malhotra A, Patil SP, et al. Clinical guideline for the evaluation, management and longterm care of obstructive sleep apnea in adults. I Clin Sleep Med.2009 Jun 15;5(3):263-76.

8. Morgenthaler TI, Aurora RN, Brown T, Zak R, Alessi C, Boehlecke B, et al. Practice parameters for the use of autotitrating continuous positive airway pressure devices for titrating pressures and treating adult patients with obstructive sleep apnea syndrome: an update for 2007. An American Academy of Sleep Medicine report. Sleep. 2008 Jan 1;31(1):141-7.

9. Stepanski EJ, Dull R, Basner RC. CPAP titration protocols among accredited sleep disorder centers. Sleep Res 1996;25:374.

10. Mokhlesi B, Tulaimat A. Recent advances in obesity hypoventilation syndrome. Chest 2007;132:1322-36.

11. Sforza E, Krieger J, Bacon W, Petiau C, Zamagni M, Boudewijns A. Determinants of effective continuous positive airway pressurein obstructive sleep apnea. Role of respiratory effort. Am J RespirCrit Care Med 1995;151:1852-6.

12. Sullivan CE, Issa FG, Berthon-Jones M, McCauley VB, Costas LJ. Home treatment of obstructive sleep apnoea with continuous positive airway pressure applied through a nose-mask. Bull Eur Physiopathol Respir 1984;20:49-54.

13. Nino-Murcia G, McCann CC, Bliwise DL, Guilleminault C, De ᄀment WC. Compliance and side effects in sleep apnea patients treated with nasal continuous positive airway pressure. West J Med 1989;150:165-9.
14. Miljeteig H, Hoffstein V. Determinants of continuous positive air way pressure level for treatment of obstructive sleep apnea. Am Rev Respir Dis 1993;147(6 Pt 1):1526-30.

15. Pevernagie DA, Shepard JW Jr. Relations between sleep stage, posture and effective nasal CPAP levels in OSA. Sleep 1992;15:162-7.

16. Stepanski EJ. The need for a standardized CPAP titration protocol and follow-up procedures. J Clin Sleep Med 2005;1:311.

17. Lin IF, Chuang ML, Liao YF, Chen NH, Li HY. Predicting effective continuous positive airway pressure in Taiwanese patients with obstructive sleep apnea syndrome. J Formos Med Assoc. 2003;102(4):215-21.

18. Loredo JS, Berry C, Nelesen RA, Dimsdale JE. Prediction of continuous positive airway pressure in obstructive sleep apnea. Sleep Breath. 2007;11(1):45-51.

19. Akahoshi T, Akashiba T, Kawahara S, Uematsu A, Nagaoka K, Kiyofuji K, et al. Predicting optimal continuous positive airway pressure in Japanese patients with obstructive sleep apnoea syndrome. Respirology. 2009;14(2):245-50.

20. Rowley JA, Tarbichi AG, Badr MS. The use of a predicted CPAP equation improves CPAP titration success. Sleep Breath. 2005; 9(1):26-32.

21. Masa JF, Jimenez A, Duran J, Capote F, Monasterio C, Mayos M, et al. Alternative methods of titrating continuous positive airway pressure: a large multicenter study. Am J Respir Crit Care Med. 2004, 1;170(11):1218-24

22. Kushida CA, Littner MR, Morgenthaler T, Alessi CA, Bailey D, Coleman Jr, et al. Practice parameters for the indications for polysomnography and related procedures: an update for 2005. Sleep. 2005;28(4):499-521.

23. Hoffstein V, Mateika S. Predicting nasal continuous positive airway pressure. Am J Respir Med 1994 150:486-488

24. Oliver Z, Hoffstein V. Predicting effective continuous positive airway pressure. Chest 2000 117:1061-1064

25. Hertegonne KB, Volna J, Portier S, De Pauw R, Van Maele G, Pevernagie DA Titration procedures for nasal CPAP: automatic CPAP or prediction formula? Sleep Med 2008 9:732-738

26. El Solh AA, Aldik Z, Alnabhan M, Grant B Predicting effective continuous positive airway pressure in sleep apnea using an artificial neural network. Sleep Med 2007 8:471-477

27. Ozen K. Basoglu \& Mehmet Sezai Tasbakan. Determination of new prediction formula for nasal continuous positive airway pressure in Turkish patients with obstructive sleep apnea syndrome Sleep Breath 2012 16:1121-1127

28. Habesoglu MA, Kokturk O. Obstrüktif Uyku Apne Sendromu Tedavisinde CPAP Titrasyon Basıncının Matematiksel Yöntemle Belirlenmesi. Turkiye Klinikleri Arch Lung 2007;8:74-7 